\title{
PENGARUH JENIS BIOMASSA PADA PEMBAKARAN PIROLISIS TERHADAP KARAKTERISTIK DAN EFISIENSIBIOARANG - ASAP CAIR YANG DIHASILKAN
}

\author{
Kemas Ridhuan, Dwi Irawan, Yulita Zanaria, Fendi Firmansyah \\ Program Studi Teknik Mesin, Fakultas Tenik, Universitas Muhammadiyah Metro \\ Jl. Ki Hajar Dewantara 15 A Metro, Lampung. \\ Email:kmsridhuan@yahoo.co.id-dwi_irawan12@yahoo.co.id \\ yulitazanaria13@gmail.com-Fendifirmansyah070@gmail.com
}

\begin{abstract}
ABSTRAK
Pirolisis merupakan proses pembakaran dengan menggunakan sedikit atau tidak ada udara. Produk yang dihasilkan dalam pembakaran pirolisis yaitu arang dan asap cair. Untuk mendapatkan hasil produk yang baik sangat dipengaruhi oleh suhu, waktu dan biomassa.Berbagai jenis biomassa yang sudah diteliti namun masih cukup banyak berbagai jenis biomassa yang memang belum dan perlu diteliti lebih lanjut. Beberapa karaktristik biomassa yaitu keras, porositas, besar butir danmassa jenis. Faktor ini yang dapat mempengaruhi proses pembakaran dan akhirnya hasil produk pirolisis yang didapat. Tujuan dari penelitian ini adalah untuk mengetahui pengaruh jenis biomassa pada pembakaran pirolisis terhadap karakteristik dan efisiensi dari hasil bio-arang dan asap cair yang di dapatkan dari masing-masing biomassa. Metode penelitian yang di lakukan yaitu memvariasikan bahan jenis biomassa pada pembakaran pirolisis dengan jenis kayu jengkol, kayu rengas dan kayu jati putih. Biomassa dibakar di dalam reaktor dengan pembakaran langsung dan asap cairnya didinginkan dikondensor. Didapat data nilai kalor, kadar abu, kadar air terbanyak, dan untuk asap cair didapat data asam asetat dan nilai $\mathrm{pH}$, Hasil penelitian menujukan nilai kalor terbaik pada jenis kayu rengas yaitu sebesar 6673,82 cal/g, dan nilai kalor terendah adalah jenis kayu jati putih yaitu sebesar 5728,89 cal/g. Untuk kadar air tertinggi terdapat pada jenis kayu jati putih yaitu sebanyak 42,22\% dan untuk kadar air terendah yaitu jenis kayu jengkol yaitu sebesar 10,18\%. Untuk kadar abu tertinggi adalah jenis kayu jengkol yaitu sebesar 50,96\% dan kadar abu terendah adalah jenis kayu jati putih yaitu sebanyak 5,35\%.Efisiensi hasil arang tertinggi pada kayu jati putih yaitu $28 \%$ Jumlah asap cair yang dihasikan tertinggi kayu rengas yaitu $86 \mathrm{ml}$ dan terendah kayu jati putih yaitu sebesar $34 \mathrm{ml}$.
\end{abstract}

Kata kunci: pembakaran, pirolisis,biomassa, arang, asap cair,.

\section{PENDAHULUAN}

Biomassa merupakan bahan bakar organik yang terbentuk dari zat-zat organik yang disusun oleh tumbuh-tumbuhanan melalui proses fotosintesis (dengan bantuan energi matahari). Biomassa meliputi limbah kayu, limbah pertanian, perkebunan, hasil hutan, komponen organik dari industri dan rumah tangga.Beberapa kandungan unsur kimia yang biasa terdapat. antara lain: zat arang atau karbon $(\mathrm{C})$, hidrogen $(\mathrm{H})$, zat asam atau oksigen $(\mathrm{O})$, zat lemas atau nitrogen $(\mathrm{N})$, belerang $(\mathrm{S})$, abu dan air, yang semuanya itu terikat dalam satu persenyawaan kimia.Karena sifatnya yang menguntungkan yaitu dengan memanfaatkannya secara lestari dan mudah di perbaharui. Sumber energi biomassa memiliki beberapa kelebihan dibandingkan 
energi fosil. Selain sifatnya dapat diperbaharui secara terus menerus juga lebih ramah terhadap lingkungan.

Energi biomassa dapat dimanfaatkan sebagai pengganti bahan bakar minyak bumi (fosil) yaitu dengan cara mengubahnya menjadi bio-arang yang memiliki nilai kalor yang tinggi. Salah satu teknologi yang dapat digunakan adalah pirolisis. Pirolisis merupakanproses dekomposisi kimia menggunakan pemanasan dengan atau tanpa menggunakan oksigen dalam pembakarannya.

Produk yang dapat dihasilkan dari proses pirolisis adalah berupa bio-arang dan asap cair. Bio-arang dihasilkan dari pembakaran di reaktor memiliki kualitas nilai kalor yang lebih baik. Dengan pengolahan biomassa tersebut menjadi bioarang pirolisis dapat meningkatkan nilai jual produk tersebut menjadi lebih baik.

Selain itu proses pirolisis juga menghasilkan produk yaitu asap cair yang terjadi di proses pengembunankondensor.Asap cair merupakan campuran larutan dari dispersi asap kayu yang dikondensasikan menjadi asap cair.Hasil asap cair yang dapat merupakan bahan pengawet produk makanan alami yang lebih aman.

\section{KAJIAN PUSTAKA}

\section{Biomassa}

Biomassa merupakan bahan bakar organik yang terbentuk dari zat-zat organik yang disusun oleh tumbuhan melalui proses fotosintesis.Biomassa diklasifikasikan ke dalam bahan bakar padat yang memiliki unsur kimia antara lain: zat arang atau karbon $(\mathrm{C})$, hidrogen $(\mathrm{H})$, zat asam atau oksigen $(\mathrm{O})$, nitrogen $(\mathrm{N})$, belerang $(\mathrm{S})$, abu dan air, yang semuanya itu terikat dalam satu persenyawaan kimia.

Menurut Hornell, (2001) bahwa kompenen dari biomassa sendiri sebagian besar terdiri dari selulosa, hemiselulosa, dan lignin. Persentase dari ketiga unsur tersebut adalah selulosa 40-45\% (untuk tumbuhan kasar dan halus), lignin 25-35\% (untuk tumbuhan halus) dan 17$25 \%$ (untuk tumbuhan kasar), hemiselulosa 20\% (untuk tumbuhan halus) dan 17-25\% (untuk tumbuhan kasar). Beberapa jenis biomassa yang digunakan pada penelitian ini yaitu kayu jengkol, kayu rengas dan kayu jati putih, biomassa ini memiliki kandungan selulosa, nignin dan pentosan yang cukup baik.

\section{Pembakaran.}

Proses pembakaran dimulai dengan reaksi fase gas, reaksi permukaan atau keduanya di ikuti dengan proses-proses lain selama peleburan, penguapan dan pirolisis. Dalam reaksi pembakaran sebenarnya, fenomena yang kompleks seperti penguapan, campuran, difusi, konveksi, konduksi panas, radiasi, dan lumenensi, akan terjadi pada kecepatan yang sangat tinggi.

Pembakaran dengan biomassa dapat mencapai suhu yang cukup tinggi, menurut Ridhuan (2015) pembakaran dengan bahan biomassa kulit kelapa muda dapat mencapai suhu $430^{\circ} \mathrm{C}$ dengan waktu 80 menit dan bahan biomassa kulit durian dapat mencapai suhu pembakaran $443^{\circ} \mathrm{C}$ dengan waktu 90 menit.

\section{Pirolisis.}

Pirolisis adalah proses dekomposisisuatu bahan pada suhu tinggi tanpa adanya udara atau dengan udara terbatas. Produk utama dari pirolisis yang dapat dihasilkan adalah arang (char), minyak, dan gas.

Menurut Wijayanti (2013) hasil pirolisis berupa tiga jenis produk yaitu padatan (charcoal/ arang), gas (fuel gas) dan cairan (bio-oil). Dan umumnya proses pirolisis berlangsung pada suhu 
di atas $300^{\circ} \mathrm{C}$ dalam waktu $4-7$ jam. Namun keadaan ini sangat bergantung pada bahan baku dan cara pembuatannya.Temperatur pirolisis untuk mereduksisampah dicapai secara optimal pada $300^{\circ} \mathrm{C}$.Beberapa faktor yang mem- pengaruhi proses pirolisis yaitu kadar air, ukuran partikel, temperatur, waktu, bahan, tipe pirolisis.

\section{Arang}

Arang adalah gumpalan karbon hitam yang dihasilkan dari pembakaran arang biasanya didapatkan dari memanaskan atau pembakaran kayu, sampah, ataupun benda padat lainnya. Arang yang hitam, ringan, mudah hancur, dan menyerupai batu bara tediri dari 85\% sampai 98\% karbon sisanya adalah benda kimia lainnya.

Karakteristik arang meliputi nilai kalor, kadar abu, kadar air. Menurut Fadillah (2015) Interaksi suhu dan waktu pirolisis sangat berpengaruh nyata terhadap rendemen tar dan arang. Proses ini juga dipengaruhi oleh bahan biomassa, karena akan menentukan kualitas dari arang karbon yang dihasilkan, seperti kekerasan dan kandungan kimia lainnya.

\section{Asap Cair.}

Asap cair merupakan suatu hasil destilasi atau pengembunan dari uap hasil pembakaran tidak langsung maupun langsung dari bahan bahan yang banyak mengandung karbon serta senyawa-senyawa lain.

Asapcair merupakan penguraian dari senyawa-senyawa organik yang terdapat dalam bahan baku sewaktu proses pembakaran pirolisis.MenurutRatnawati (2010) bahwa hasil maksimum bio-oil (47,3\%) dapat diperoleh dan bekerja pada tingkat menengah untuk suhu operasi $\left(500^{\circ} \mathrm{C}\right)$. Suhu merupakan faktor yang paling penting, memiliki efek positif yang signifikan terhadap produk hasil bio-oil. Semakin tinggi temperatur pirolisis yang diberikan maka produk padatan (Char) yang dihasilkan semakin sedikit.

\section{Kondensasi.}

Kondensasi atau pengembunan adalah perubahan wujud benda dari uap ke wujud cairan. Kondensasi terjadi ketika uap didinginkan menjadi cairan pada suatu tempat. Kondensasi merupakan proses yang menentukan untuk mendapatkan hasil asap cair yang optimal.

Berdasarkan Mappiratu (2009) bahwa peralatan destilator-pirolisis dan waktu pembakaran berpengaruh terhadap rendemen asap cair yang dihasilkan. Penggunaan model E dan waktu pembakaran 2,5 jam menghasilkan asap cair dengan rendemen tertinggi, yakni 6,03 \%. Model peralatan destilator-pirolisis tidak berpengaruh terhadap kadar fenol, karbonil, asam asetat dan keasaman asap cair yang dihasilkan. Asap cair sabut kelapa mengandung fenol 3,03 \%, karbonil $10,26 \%$ dan asam asetat $9,22 \%$.

\section{METODE PENELITIAN}

Bahan biomassa yang digunakan yaitu kayu jengkol, kayu rengas dan kayu jati putih. Kapasitas biomassa yang dimasukan kedalam reaktor sebanyak $30 \mathrm{~kg}$. proses pembakaran yang digunakan yaitu pembakaran langsung.

Proses pengujian : biomassa dimasukan ke dalam reaktor, kemudian biomassa tersebut dibakar, setelah itu tutup reaktor. Hubungkan reaktor dan kondensor dengan pipa aliran.Asap cair akan keluar pada ujung kondensor, tunggu hingga selesai yaitu asap cair tidak menetes lagi. Setelah itu ukur bio-arang dan asap cair yang didapat.

Uji lab bio-arang dan asap cair dilakukan di lab polinela untuk mengetahui nilai kalor, kadar air, kadar abu dan asam asetat. 


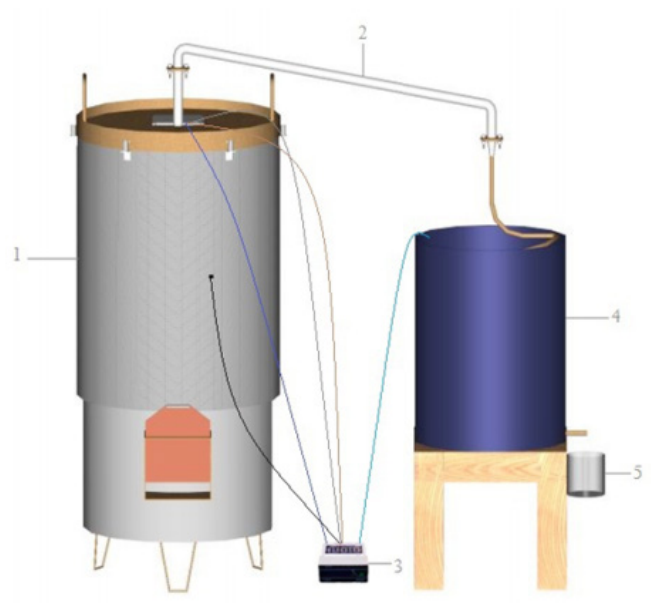

Gambar 1. Rangkaian ReaktorPirolisis

Keterangan Gambar :

1. Reaktor

2. Pipa penghubung

3. Termokopel

4. Kondensor

5. Wadah asap cair

\section{HASIL DAN PEMBAHASAN.}

Data hasil pengujian yang didapat untuk berbagai jenis bahan biomassa, terhadap waktu, suhu, kadar air, kadar abu, asam asetat, nilai kalor dan lainnya, yaitu :

Tabel 1. Hasil pengujian di Reaktor

\begin{tabular}{cccc}
\hline $\begin{array}{c}\text { Jenis } \\
\text { Biomassa }\end{array}$ & $\begin{array}{c}\text { Waktu } \\
\text { (menit) }\end{array}$ & $\begin{array}{c}\text { Suhu } \\
\text { Gas } \\
\text { asap }\end{array}$ & $\begin{array}{c}\text { Suhu } \\
\text { Api Bio }\end{array}$ \\
\hline Kayu Jengkol & 190 & 473 & 570 \\
Kayu Rengas & 180 & 563 & 526 \\
Kayu Jati Putih & 170 & 554 & 478 \\
\hline
\end{tabular}

Tabel 2. Hasil Lab kimia

\begin{tabular}{ccccc}
\hline $\begin{array}{c}\text { Jenis } \\
\text { Biomassa }\end{array}$ & $\begin{array}{c}\text { Kalori } \\
(\mathbf{c a l} / \mathbf{g})\end{array}$ & $\begin{array}{c}\text { Air } \\
(\%)\end{array}$ & $\begin{array}{c}\text { Abu } \\
(\%)\end{array}$ & $\begin{array}{c}\text { Efisiensi } \\
\text { Arang } \\
(\%)\end{array}$ \\
\hline $\begin{array}{c}\text { Kayu } \\
\text { Jengkol }\end{array}$ & 7475,87 & 10,16 & 50,96 & 25 \\
$\begin{array}{c}\text { Kayu } \\
\text { Rengas } \\
\text { Kayu Jati } \\
\text { Putih }\end{array}$ & 7631,87 & 38,70 & 15,85 & 20 \\
\hline
\end{tabular}




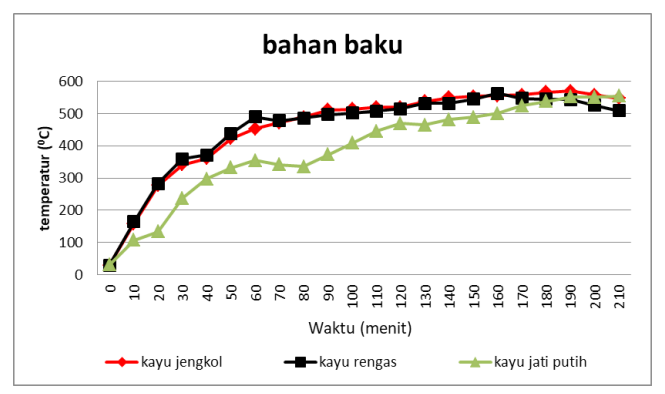

Gambar 2.Grafik suhuApitiap biomassa

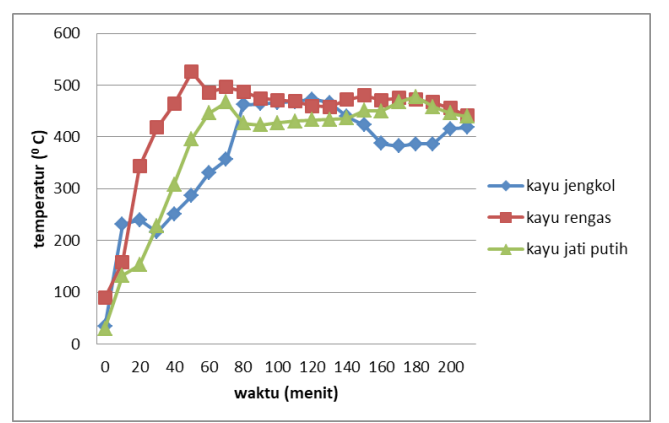

Gambar 3.Grafik suhu Gas-Asap tiap biomassa

Berdasarkan gambar 2di atas yaitu grafik suhu pada api biomassa terlihat bahwa perubahan suhu tiap biomassa memiliki kencendrungan yang sama. Suhu tertinggi hampir sama terjadi pada biomassa kayu jengkol dan rengas. Dimana suhu terus naik dari awal hingga pada menit ke 60 suhu mencapai $500^{\circ} \mathrm{C}$ an. Setelah itu suhu cendrung konstan hingga mencapai suhu tertinggi $570^{\circ} \mathrm{C}$. Hal ini dikarenakan biomassa kayu jengkol dan rengas memiliki tekstur yang hampir sama yaitu lunak dan berserat, dimana pembakarannya akan sangat mudah terjadi. Berbeda dengan kayu jati putih suhunya lebih kecil karena kayunya sedikit keras sehingga pembakarannya akan sedikit susah. Proses pengembunan asap cair hingga pada menit ke 210, karena asap cair sudah tidak keluar lagi.

Kemudian pada gambar 3, Grafik suhu pada gas-asap pembakaran biomassa, terlihat bahwa kecendrungannya hampir sama ke biomassa tersebut. Suhu tertinggi pada gas asap kayu rengas yaitu $563^{\circ} \mathrm{C}$ dan yang rendah gas asap kayu jengkol. Asap tersebut didinginkan di kondensor dan menjadi cairan.

Tabel 3.Jumlah Arang yang di hasilkan tiap biomassa.

\begin{tabular}{ccc}
\hline Jenis Biomassa & $\begin{array}{c}\text { Biomassa } \\
\text { Awal (Kg) }\end{array}$ & $\begin{array}{c}\text { Setelah menjadi } \\
\text { Arang (Kg) }\end{array}$ \\
\hline Kayu Jengkol & 10 & 2,5 \\
Kayu Rengas & 10 & 2 \\
Kayu Jati Putih & 10 & 2,8 \\
\hline
\end{tabular}


Tabel 4. Jumlah Asap cair yang dihasilkan

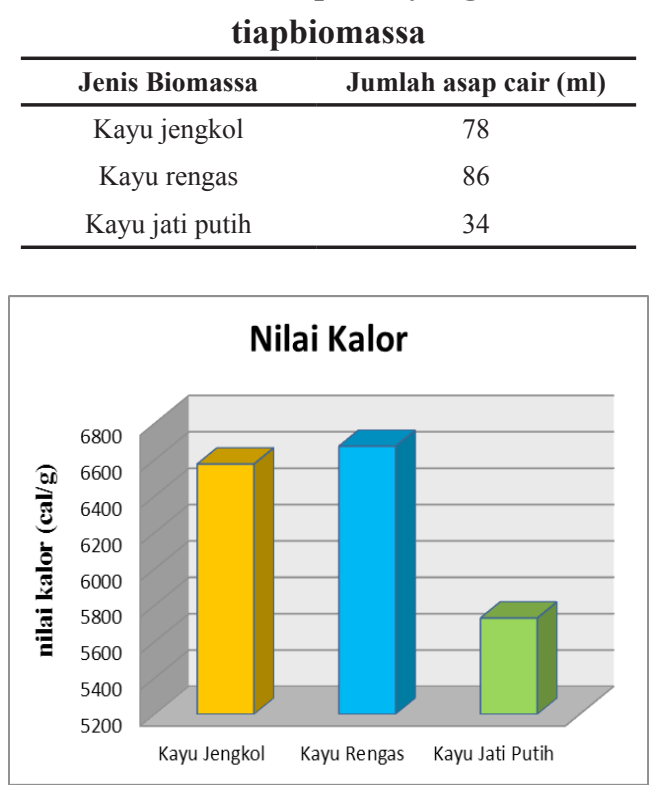

Gambar 4.Grafik Nilai Kalor tiap biomassa

Pada tabel 4, jumlah asap cair yang dihasilkan bahwa untuk jenis kayu rengan memiliki hasil asap cair yang lebih banyak yaitu $86 \mathrm{ml}$ dibandingkan kayu jati putih $34 \mathrm{ml}$. Ini sesuai dengan suhu pembakaran yang terajdi seperti pada gambar 3, bahwa semakin tinggi suhu pembakaran maka hasil asap cairnya juga akan lebih banyak. Hasil ini sesuai dengan penelitian Wibowo (2012) bahwa Rendemen tertinggi diperoleh pada perlakuan suhu 500 $\square$, selama 7 jam yaitu sebesar $48,8 \%$ dan yang terendah diperoleh pada perlakuan suhu $200 \square$ selama 5 jam. Terdapat kecenderungan semakin tinggisuhudanlamawaktupirolisis,asapcairyang dihasilkan semakin tinggi.

Pada gambar 4 nilai kalor biomassa terlihat bahwa kayu rengas memiliki nilai kalor tertinggi yaitu $6673,82 \mathrm{cal} / \mathrm{gr}$, dan nilai kalor terendah terdapat pada jenis kayu jati putih yaitu 5728,89 $\mathrm{cal} / \mathrm{gr}$. Dari sini terlihat bahwa ada pengaruh suhu terhadap nilai kalor bio-arang. Hasil ini sesuai dengan penelitian Saparudin (2015) nilai kalor briket bioarang tertinggi yaitu 4252,67 kal/gr ditunjukkan pada temperatur pirolisis $275^{\circ} \mathrm{C}$ sedangkan, untuk nilai kalor terendah $3821,33 \mathrm{kal} /$ gr pada temperatur $225^{\circ} \mathrm{C}$. Dengan kenaikantemperatur dan pengaturan aliran partikel biomassa maka semakin banyak ikatan baik antar atom $\mathrm{C}$ maupun atom $\mathrm{C}$ dengan $\mathrm{H}, \mathrm{O}$ yang terputus maka kadar C (arang) semakin murni maka nilai kalor juga semakin tinggi.

Peningkatan nilai kalor arang yang beriringan dengan peningkatan suhu pirolisis dapat diakibatkan karena peningkatan suhu pirolisis meningkatkan penguapan volatile matter sehingga mengakibatkan penurunan kadar air dan menyisakan karbon pada arang sehingga berakibat pada peningkatan nilai kalor arang tersebut. Penurunan nilai kalor arang pada kayu jati putih, ini terjadi karena vollatilematter yang terkandung mengalami devolatilisasi lanjutan dan lebih banyaknya lignin yang terdekomposisi.

Penentuan kadar abu bertujuan untuk menentukan kandungan oksida logam dalam arang. Dari gambar 5 kadar abu, di ketahui bahwa kadar abu terbanyak terdapat apada jenis kayu jengkol yaitu 50,96 \% dan kadar abu terendah terdapat pada jenis kayu jati putih yaitu sebanyak 5,35 \%. Hal ini dikarenakan semakin meningkatnya suhu dan waktu karbonisasi maka kadar abu yang terkandung akan semakin tinggi. Dan sesuai karena kayu jengkol memiliki suhu pembakaran yang lebih tinggi dibanding biomassa yang lain. 


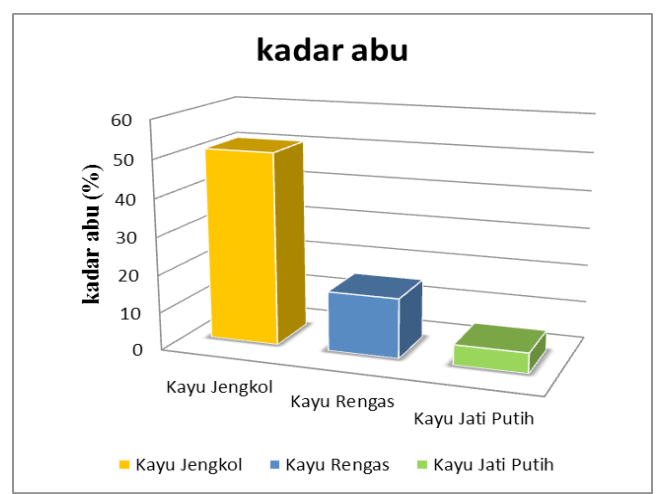

Gambar 5.Grafik Kadar Abu tiap biomassa

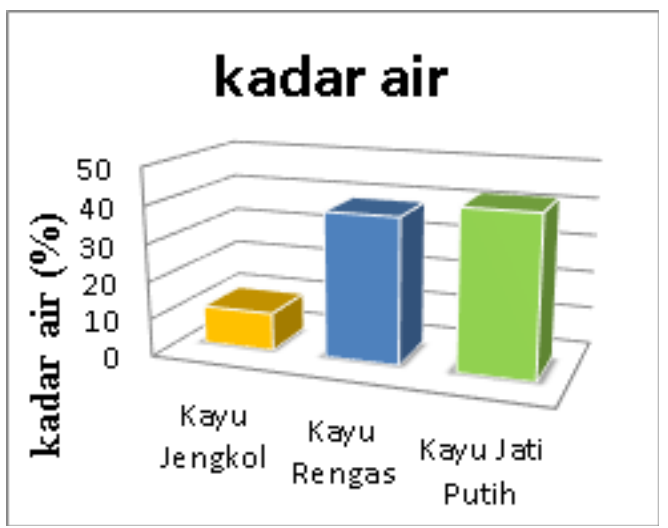

Gambar 6.Grafik Kadar Air Arang tiap biomassa

Pada gambar 6 mengenai kadar air, kayu jengkol memiliki kadar air yang lebih kecil yaitu $10,16 \%$, dibanding kayu jati putih yaitu $40,22 \%$.Hal ini sesuai bahwa semakin lama waktu pembakaran maka kadar air pada bio-arang akan semakin banyak. Hal ini disebabkan karena semakin lama waktu karbonisasi, maka pori - pori dari arang akan makin terbuka, terjadi kontak langsung antara arang yang bersifat higroskopis dengan udara sehingga arang banyak menyerap uap air. Dan juga pada suhu pembakaran, semakin tinggi suhu maka kadar air yang ada semakin sedikit, karena sebagian besar kadar air tersebut akan teruapkan ke udara.

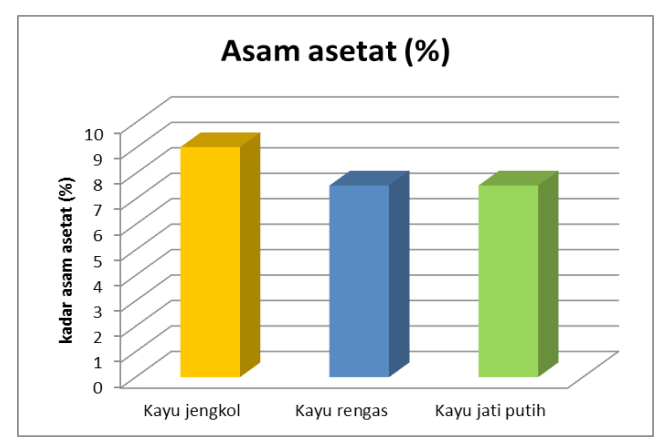

Gambar 7.Grafik Kadar Asam Asetat Asap Cair tiap biomassa

Dari gambar 7, grafik kadar asam asetat, terlihat bahwa kandungan asam asetat terbanyak yaitu pada jenis kayu jengkol yaitu sebanyak $8,64 \%$ dan untuk kayu jati putih dan rengas hamper sama yaitu $7,15 \%$. Hasil pengamatan kadar asam asap cair sebelum distilasi menunjukkan bahwa asap cair memiliki kadar asam yang lebih kecil pada suhu pembakaran yang lebih tinggi. 
Perbedaan jumlah kadar asam ini dikarenakan asam organik yang dihasilkan dari dekomposisi komponen hemiselulosa dan selulosa mengalami proses pirolisis pada suhu pembakaran dibawah $300^{\circ} \mathrm{C}$. Asap cair pada suhu pembakaran $500^{\circ} \mathrm{C}$ memiliki kadar asam yang lebih rendah karena menurut Maga (1988) pada suhu pembakaran diatas $300^{\circ} \mathrm{C}$ senyawa-senyawa fenol, guaikol, siringol telah terdekomposisi dari lignin sehingga mempengaruhi kadar asam dari asap cair.

\section{Efisiensi Arang (\%)}

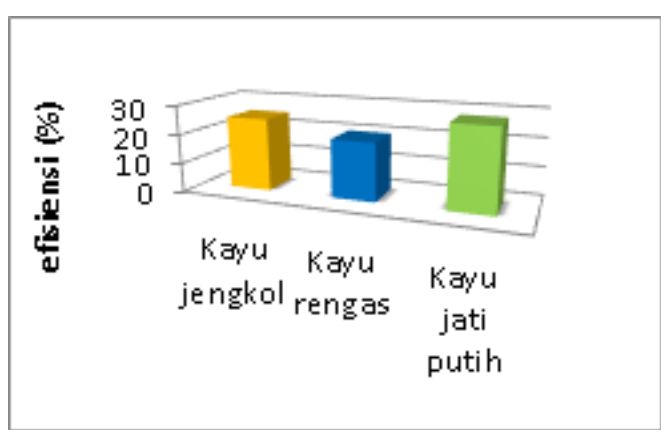

Gambar 8.Grafik Efisiensi hasil Arang tiap Biomassa

Dari gambar 8, grafik hasil arang di ketahui bahwa efisiensi biomassa terbaik yaitu pada jenis kayu jati putih yaitu $28 \%$ dan untuk efisiensi terendah yaitu pada jenis kayu rengas yaitu sebanyak 20\%, dikarenakan suhu pembakaran yang merata dan konstan akan mengoksidasi bahan padatan biomassa menjadi arang akan lebih baik dan teratur atau terukur bertahap. Sesuai bahwa kayu jati putih dengan suhu pembakaran kecil dibanding kayu rengas.Kemudian laju pembakaran yang lebih lambat dan suhu perlakuan yang rendah.Kenaikan temperatur pirolisis menyebabkan kehilangan massa semakin besar sehingga faktor penyusutan juga semakin besar. Faktor penyusutan juga merupakan akibat proses dekomposisi thermal yang terjadi pada biomassa.

\section{Efisiensi Asap Cair (\%)}

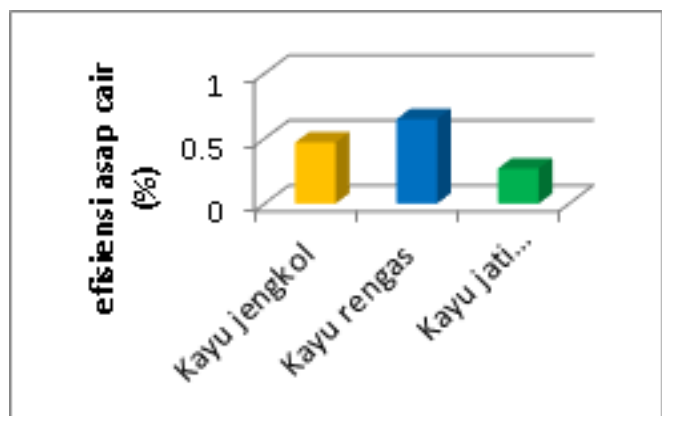

Gambar 9.Grafik Efisiensi Asap Cair tiap biomassa

Dari Gambar 9, grafik efisiensi asap cair terlihatbahwa hasil tertinggi ialah pada jenis kayu rengas yaitu sebanyak $0,65 \%$ dan untuk efisiensi asap cair terendah adalah pada jenis kayu jati putih yaitu sebanyak $0,27 \%$. Semakin tinggi suhu dan lama waktu maka semakin banyak asap cair yang dihasilkan. Hal ini dikarenakan bahwa semakin lama waktu pembakaran maka semakin banyak asap yang berproduksi dan semakin tinggi suhunya maka akan semakin banyak padatan biomassa yang teroksidasi dan terurai menjadi asap dan pada gilirannya menjadi cairan. 


\section{KESIMPULAN.}

1. Karakteristik arang

a. Nilai kalor tertinggi yaitu kayu rengas yaitu sebanyak $6673,59 \mathrm{cal} / \mathrm{g}$

b. Kadar air tertinggi yaitu pada jenis kayu jati putih yaitu sebanyak $42,22 \%$.

c. Kadar abu tertinggi adalah jenis kayu jengkol yaitu 50,96\%.

2. Karakteristik asap cair.

a. Asap asetat yertinggi terdapat pada jenis kayu jengkol yaitu sebanyak 9,04 \%

b. massa jenis asap cair tertinggi terdapat pada jenis kayu jati putih yaitu sebanyak 0,79 $\mathrm{g} / \mathrm{ml}$

3. suhu tertinggi yang di hasilkan pada biomassa adalah pada kayu jengkol suhuyaitu $570^{\circ} \mathrm{C}$, dan untuk kayu rengas adalah $526^{\circ} \mathrm{C}$, dan untuk jati putih adalah $478^{\circ} \mathrm{C}$.

4. Efisiensi hasil arang dari biomassa tertinggi terdapat pada jenis kayu jati putih yaitu $28 \%$ dan untuk efisiensi asap cair tertinggi adalah jenis kayu rengas yaitu $0,65 \%$.

5. Jumlah asap cair yang dihasikan tertinggi kayu rengas yaitu $86 \mathrm{ml}$ dan terendah kayu jati putih yaitu sebesar $34 \mathrm{ml}$.

\section{UCAPAN TERIMA KASIH}

Ucapan terima kasih disampaikan kepada Direktorat Riset dan Pengabdian Masyarakat Kementrian Riset Teknologi dan Pendidikan Tinggi Republik Indonesia yang sudah mendukung penelitian ini dalam program Penelitian Strategi Nasional Nomor : 2108/SP2H/K2/KM/2018. Dan tidak lupa pula kepada Rektor Universitas Muhammadiyah Metro serta Ketua Lembaga Penelitian dan Pengabdian kepada Masyarakat Universitas Muhammadiyah Metro.

\section{DAFTAR PUSTAKA}

[1] Fadillah, Haris,. Alfiarty, Alivia,. 2015, The Influence Of Pyrolysis Temperature And Time To The Yield And Quality of Rubber Fruit (Hevea brasiliensis) Shell Liquid Smoke, Prosiding Seminar Nasional Teknik Kimia “Kejuangan” ISSN 1693-4393, Yogyakarta.

[2] Hornell, C., 2001, "Thermochemical and Catalitic Upgrading in a Fuel Contex: Peat, Biomass, and Alkenes", Royal Institute of Technology, Departement of Chemical Engineering and Thechnology, Stockholm

[3] Maga, J.A. 1988. Smoke in Food Processing. CRC Press, Florida.

[4] Mappiratu, 2009. Kajian Teknologi Produksi Asap Cair Dari Sabut Kelapa, Media Litbang Sulteng 2 (2), ISSN: 1979-5971. Hlm. 104-109

[5] Ratnawati,.Hartanto, Singgih, 2010, Pengaruh Suhu Pirolisis Cangkang Sawit Terhadap Kuantitas Dan Kualitas Asap Cair, Indonesian Journal Of Materials Science, Vol. 12, No. 1, Hal : 7 - 11 Issn : 1411-1098

[6] Ridhuan, Kemas. Arya, Sepit., 2015. Karaktristik Pembakaran berbagai Jenis Bahan Limbah Biomassa dengan Menggunakan Proses Nonkarbonisasi. Jurnal Teknik Mesin “Turbo". Volume 4 Nomor 1. ISSN: 23016663

[7] Saparudin,Syahrul, Nurchayati2015, Pengaruh Variasi Temperatur Pirolisis Terhadap Kadar Hasil Dan Nilai Kalor Briket Campuran Sekam Padi-Kotoran Ayam, Jurnal Dinamika Teknik Mesin, Vol. 5, No.1, ISSN: 2088-088X.

[8] Wibowo, santiyo, 2012, Karakteristik Asap CairTempurung Nyamplung, Jurnal Penelitian Hasil Hutan Vol. 30 No. 3, Hal. 218-227 ISSN:0216-4329,Terakreditasi No.:443/AU2/ P2MI-LIPI/08/2012 
[9] Wijayanti, Widya. Nur, Mega Sasongko. dkk., 2013. Metode Pirolisis Untuk Penanganan Sampah PerkotaanSebagai Penghasil Bahan Bakar Alternatif, Jurnal Rekayasa Mesin, Vol.4, No.2, ISSN: 0216-468X, Hlm. 85-92 